\title{
Role of the Hepatic Parenchyma in Liver Transplant Tolerance: A Paradigm Revisited
}

\author{
Volker Benseler ${ }^{a}$ Szun Szun Tay ${ }^{b}$ David G. Bowen ${ }^{b}$ Patrick Bertolino ${ }^{b}$

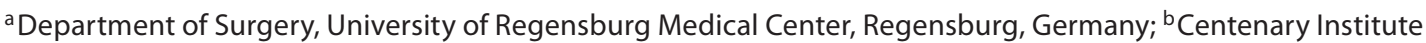 \\ and AW Morrow Gastroenterology and Liver Centre, University of Sydney and Royal Prince Alfred Hospital, \\ Sydney, N.S.W., Australia
}

\section{Key Words}

Liver $\cdot$ Transplantation $\cdot$ Tolerance $\cdot T$ cells $\cdot$ Dendritic cells

\begin{abstract}
Unlike other solid organs, liver transplants are spontaneously accepted in a wide range of animal models. In the clinic, transplanted livers also display privileged immunological properties allowing weaning of immunosuppression therapy in up to $20 \%$ of selected patients. To explain this phenomenon, many studies have focused on the role of donor-derived 'passenger' leukocytes that are thought to induce antigen-specific tolerance by migrating from the graft into recipient secondary lymphoid tissues. Although convincing evidence exists that these cells are able to elicit antiallograft $T$ cell hyporesponsiveness, several studies argue against an exclusive role for this cell population and even question whether it is critical in conferring donor MHC-specific tolerance. Instead, these studies suggest that the hepatic parenchyma plays a more critical role in this phenomenon. In this review we will reinterpret the results of old and more recent literature in light of recent advances in the field of liver immunology to explain the contribution of both passenger leukocytes and liver tissue in the liver tolerance effect.
\end{abstract}

Copyright $\odot 2011$ S. Karger AG, Basel

\section{KARGER}

Fax +4161306 1234

E-Mail karger@karger.ch

www.karger.com
(C) 2011 S. Karger AG, Basel

0257-2753/11/0294-0391\$38.00/0

Accessible online at:

www.karger.com/ddi

\section{Introduction}

Liver diseases represent an increasing health burden and an enormous human and financial cost to the community, and liver transplantation is currently the only long-term therapeutic option for patients with end-stage liver disease. While immunosuppressive medication prevents allograft rejection by suppressing the patient's immune responses toward the donor liver, these drugs place the recipient at risk of cardiovascular disease, malignancy and infection. Clinicians strive to minimize immunosuppressive medication without increasing the risk of rejection. Ultimately, the goal is to achieve transplantation tolerance, a state whereby the recipient, in the absence of immunosuppression, does not mount an immune response against the donor organ, while maintaining the capacity to respond to pathogens and tumors.

Liver transplants are unique compared to other solid organ grafts: they are spontaneously accepted in a wide range of animal models, including across completely MHC-mismatched mouse and rat inbred strain combinations [1]. Liver transplants can also reverse ongoing rejection of previous organ allografts from the same donor strain, including heart [2], pancreas [3] and skin [4, 5].
Dr. Patrick Bertolino

AW Morrow Gastroenterology and Liver Centre Centenary Institute of Cancer Medicine and Cell Biology Locked Bag No 6, Newtown 2042, NSW (Australia) E-Mail p.bertolino@centenary.org.au 
Human liver transplants require less immunosuppression than other organs [6] and, unlike renal transplants, early rejection episodes do not affect long-term graft survival [7]. In about $20 \%$ of selected liver recipients, immunosuppression can even be weaned off completely without rejection of the allograft [8-10], although specific biomarkers to identify such patients are still lacking [11].

Various models have been proposed to explain liver transplant tolerance. Most studies in rats have highlighted both the role of donor passenger leukocytes and the liver tissue in this process, but their relative contribution and mechanisms are still unknown. Passenger leukocytes migrate to secondary lymphoid tissues where they are thought to induce an 'abnormal' activation of graftreactive $\mathrm{T}$ cells, leading to tolerance $[12,13]$. The mechanisms by which the liver tissue induces tolerance are even more enigmatic. In this review, we will reinterpret old and recent findings to explain how the liver tissue contributes to the spontaneous acceptance of liver allografts.

\section{Liver Transplantation Is Associated with the Induction of Tolerance}

In 1969, Sir Roy Calne [14, 15] reported for the first time that liver transplants were accepted in outbred pigs in the absence of immunosuppressive drugs, opening a new area of research in transplantation immunology. Liver acceptance between outbred individuals has been confirmed in several other species [5, 16-19]. Using inbred mouse and rat strains, it was confirmed that liver transplants were accepted between several complete MHC mismatch barrier combinations [5, 16-18]. In contrast, kidneys were rejected at day 12 [20], while hearts underwent rejection after 8 days [21]. Likewise, in clinical practice, unlike renal transplants, HLA-matching of liver transplant recipients and donors is not necessary [22-25].

A decade after the pioneering observation by Calne, Kamada and colleagues were able to demonstrate, in rats, that recipients of liver grafts also accepted subsequent skin or heart transplants from the same donor strain while rejecting third-party grafts [5, 16-18]. Liver transplants were also able to reverse severe ongoing rejection of previous organ transplants from the same strain, including heart [2], pancreas [3] and skin [4, 5, 17]. Liver transplants could reverse ongoing rejection even 6 days after transplantation of the heart, but only in $50 \%$ of cases, while both organs were rejected when the liver was transplanted after 6 days [26], indicating that there was an 'all-or-nothing' threshold between rejection and ac- ceptance. These findings are consistent with the clinical observation that the combined transplantation of a liver with another organ from the same donor results in fewer rejection episodes of the organ, including kidney [27], heart [28], lung and multiorgan recipients [29]. These experiments reinforced the view that liver grafts were not ignored by the immune system, but rather induced antigen-specific tolerance.

\section{Histology of Tolerant and Rejecting Liver Grafts}

Several studies have followed to dissect mechanisms of tolerance associated with spontaneous liver transplant acceptance. In mice, the surgery is extremely difficult. For this reason, most studies have been performed in rats in which both tolerant and rejecting strain combinations have been reported. PVG rat strain livers transplanted to completely MHC-mismatched DA-strain recipients $(\mathrm{PVG} \rightarrow \mathrm{DA})$ did not reject the liver for more than 100 days, even though they received no immunosuppression $[18,30]$. In contrast, PVG $\rightarrow$ Lewis liver allografts were rapidly rejected [18]. Spontaneous acceptance of the PVG liver into the DA recipient was associated with hyporesponsiveness of the recipient to another graft from the same donor while rejecting a third-party organ at a normal pace, suggesting that it had induced donor-specific tolerance. Many groups have used these strain combinations to determine whether there are differences between tolerant and rejecting combinations.

The presence of cellular infiltrates and focal necrosis of hepatocytes in tolerant liver grafts during the first 2 weeks confirmed that tolerant liver transplants were not ignored by the recipient's immune system, but instead tolerance was associated with vigorous activation of the adaptive immunity [26]. Interestingly, experiments in the rat allograft model indicated that allograft damage occurred early in the post-transplant period, irrespective of whether the allograft was rejected or accepted [26], raising the question of how immune activation and allograft damage could alter the final outcome. By comparing the composition of infiltrates in the liver graft of accepting and rejecting strain combinations, Sun et al. [31] showed that there were minor differences in the proportion of $\mathrm{CD} 11 \mathrm{~b}+$ (macrophages) and CD3+ cells (T cells). However, the liver of tolerant recipients contained a higher proportion of IgD+ cells (B cells). The significance of this difference was not clear. Other studies have confirmed that there is little difference in liver $\mathrm{T}$ cell infiltrates between rejecting and accepting strain combinations [32]. 
Cellular infiltration in liver grafts has often been associated with apoptosis of both hepatocytes and infiltrating leukocytes in animal models, but also in clinical liver transplantation [33-35]. Interestingly, apoptosis of lymphocytes also occurred in parallel in lymphoid tissues $[36,37]$, suggesting that recipient $\mathrm{T}$ cells might became apoptotic as a result of their activation. In acute rejection, the level of apoptosis within the graft correlated with the severity of the rejection $[33,35]$, and reducing apoptosis by knocking down IL-2 prevented rejection in the LEW to BN rat strain combination [38]. On the other hand, apoptosis was also observed in liver transplants that were accepted, and in the study by Qian et al. [39], reducing apoptosis in the liver by IL-2 treatment converted liver transplant tolerance to rejection $[39,40]$. To date, no definitive study has been performed to determine if it is apoptosis of the liver tissue, apoptosis of liver infiltrates or apoptosis of leukocytes in secondary lymphoid organs that best correlates with liver transplant tolerance.

\section{Role of Donor-Derived Leukocytes in Liver Transplantation Tolerance}

\section{Passenger Leukocytes and Microchimerism}

The liver contains both resident leukocytes (e.g. Kupffer cells) and leukocytes that are able to recirculate to lymphoid tissues following liver transplantation [also known as passenger leukocytes (PLs)]. By migrating to lymphoid tissues, PLs are thought to induce abortive activation of recipient leukocytes leading to tolerance [41]. It was proposed that the liver would be more prone to induce tolerance than other solid organs due to its larger size [42] and/or because it harbors a higher number of migratory donor PLs [41]. Consistent with this proposal, several organs from the same donor transplanted at the same time survived longer than single organ transplants in both small animals [42] as well as in humans [43-45]. The mechanisms and exact contribution of this particular process to the spontaneous acceptance of liver grafts and liver tolerance 'effect' remain unclear. Depletion of donor PLs induced rejection [46-48], while the reconstitution of donor PLs either through i.v. infusion $[42,47]$ or parking the liver in a donor strain animal [46] was able to restore tolerance. These experiments led some investigators to suggest that this is the major pathway by which liver PLs induced tolerance.

This view was consolidated when, in 1992, Starzl et al. [49] demonstrated that liver transplant patients com- pletely weaned off all immunosuppression drugs displayed long-term donor cell chimerism. The model of 'microchimerism', which describes the existence of a very low $(<1 \%)$ frequency of hematopoietic donor cells within the recipients blood and tissue, was born. According to this model, the outcome of liver transplants is determined by a limited graft-versus-host and host-versus-graft response [50]. These 'two-way mixed lymphocyte reaction' would reach a balance after several months during which immunosuppressive treatment could be decreased and eventually completely stopped [51]. However, microchimerism alone could not explain spontaneous acceptance of liver grafts, as the existence of microchimerism failed to identify patients suitable for successful weaning of immunosuppressive therapy $[52,53]$. Instead, it has been postulated that microchimerism could represent a consequence of tolerance rather than its cause [54].

Evidence supporting a role for donor PLs has also been provided in a rat liver transplant model, where the donor liver was retransplanted into a recipient after being 'parked' in another recipient of the same strain for several weeks. The livers which were composed of donorderived parenchymal and liver-restricted leukocytes and recipient-derived PLs, were rejected following retransplantation [55]. Similar results were obtained by depletion of donor leukocytes within the graft using irradiation [48], while reconstitution of an irradiated liver by 'parking' it in a recipient rat of the donor strain for $36 \mathrm{~h}$ before transplanting into an allogeneic host could restore tolerance $[46,56]$. In this context, it is important to note that irradiation might do more than depleting leukocytes. For example, irradiation induces some inflammation and upregulation of adhesion molecules [57]. In addition, NKG2D ligands MICA/B and ULBP1-3 proteins have been described as being upregulated following inflammation [58]. These changes might alter the immune response independently of PLs.

\section{Use of Donor Splenocytes to Mimic the Role of PLs}

Microchimerism and its mechanisms are still debated [1], but this model has inspired several investigators to examine the role of PLs in inducing antigen-specific $\mathrm{T}$ cell tolerance in a transplant setting. Infusion of donor leukocytes at the time of transplantation (to mimic PLs migrating out of the graft) has been used in several mouse and rat transplant models to prolong graft survival [59, 60]. These studies recapitulate the ability of donor PBMC to induce tolerance (the so-called 'blood transfusion effect' [61]) and have demonstrated some (sometimes limited) success in extending graft survival. This was highly 
dependent on the nature of the transplanted organ, the species and the number of PLs adoptively transferred. In rats, donor-derived splenocytes administered just before liver transplantation induced donor-specific tolerance $[42,47]$ and led to acceptance of liver allografts that were normally rejected [62]. Administration of donor splenocytes was also able to induce tolerance to rat kidney allografts [62]. However, administration of donor splenocytes was unable to convert skin allograft rejection into acceptance [42], nor heart allograft rejection into tolerance [59]. In most cases, donor leukocytes alone were not able to induce long-term acceptance of allogeneic transplants. This could only be achieved when the recipients also received other treatments either pharmacologically (e.g. calcineurin-inhibitors) $[59,63]$ or by blocking costimulatory molecules, signal 2 in T cell activation, using antibodies (e.g. CD154 mAb) [64].

The nature of the donor splenocytes contributing to inducing tolerance or prolongation of graft survival has been reviewed elsewhere and is not the focus of this review [1]. In summary, although T cells [42, 55], B cells [65, 66] and dendritic cells (DCs) [67] have been shown to play some role in inducing tolerance, the nature of the cellular subset, and whether the spleen and lymph nodes play a similar role in activating and/or deleting alloreactive $\mathrm{T}$ cells remains unsolved. Although they are able to induce tolerance, it is also not clear whether the injection of donor splenocytes into transplant recipients is representative of the migration of liver PLs after transplantation.

\section{Intrahepatic Leukocytes}

The liver harbors different subsets of lymphocytes that differ from those of the blood and spleen, including hematopoietic stem cells, unique subsets of DCs [67, 68], and a high proportion of natural killer (NK) and natural killer T (NKT) cells [69]. It is thus possible that it is the qualities of liver leukocytes, rather than the quantity, that induces tolerance.

\section{Role of Liver DCs}

The total number of DCs in a normal liver is up to fivefold [70] higher than in other solid organs, but the volume density is the lowest of all organs [70]. Most studies agree that freshly isolated hepatic DCs are immature and are less immunogenic than splenic DCs $[71,72]$. They express low levels of MHC class II and costimulatory molecules (CD80 and CD86), a finding consistent with their poor allostimulatory ability in MLR assays [73, 74]. They also secrete IL-10 [75] and display a higher threshold for activation than splenic DCs due to decreased expression of
Toll-like receptor 4 [76]. It has been proposed that hepatic DCs induce apoptosis, possess immune regulatory/ suppressive functions [77] and might participate in the generation of regulatory $\mathrm{T}$ cell $\left(\mathrm{T}_{\text {reg }}\right)$ populations $[78,79]$. However, their immature phenotype and location in the portal tracts argue against their role in inducing spontaneous acceptance of liver transplants. Consistent with limited DC contribution in the liver tolerance effect, administration of the Flt 3 ligand, which increases the number of DCs, caused rejection of liver allografts [80]. In humans, BDCA-1+ DCs were the most prevalent DC subset in the liver in contrast to CD16+ DCs in the blood. In direct comparison, between human liver and blood, DCs produced large amounts of IL-10 and induced FoxP3positive $\mathrm{T}_{\text {reg }}$ and IL- 4 producing Th2 cells, while being less effective in inducing proliferation of allogenic $\mathrm{T}$ cells [81].

Although the role of hepatic DCs in inducing spontaneous tolerance to liver allografts remains speculative, manipulation of DCs has the potential to be used as a therapy. Several investigators have shown that human and mouse DC manipulated ex vivo with cytokines such as IL-10 [82], TGF- $\beta$ [83] and TNF- $\alpha$ [56], or pharmacological reagents like dexamethasone or mitomycin C [84] were able to promote antigen-specific hyporesponsiveness.

In addition to DCs, the liver contains sufficient hematopoietic stem cells to reconstitute lethally irradiated recipients $[85,86]$. These cells have been suggested to play some role in tolerance by migrating into the recipient thymus and inducing negative selection of donor-derived $\mathrm{T}$ cells $[87,88]$. Although this might occur and be important for the long-term maintenance of tolerance and the establishment of microchimerism, it is unlikely that it contributes significantly to establish tolerance, as thymectomy does not interfere with liver transplant tolerance $[41,89]$.

\section{Role of NK/NKT Cells}

$\mathrm{NK}$ and CD8+ CD69+ lymphocytes expressing high levels of MHC class II and CD25 are detected in portal tracts and perisinusoidal areas of liver transplants [90], indicating that they might play some role in inducing tolerance by interacting with resident recipient leukocytes [91].

Some in vitro experiments indicate that both NK and NKT cells display some indirect tolerogenic properties that require the presence of hepatocytes. NK cell interaction with hepatocytes in vitro led to NKG2A-dependent secretion of TGF- $\beta$, generating tolerogenic DCs which in 
turn induced CD4+ CD25+ $\mathrm{T}_{\text {reg }}$ [92]. Likewise, hepatocytes induced NKT cells to secrete IFN- $\beta$ and tolerogenic CD8+ T cells secreting IL-10 [93].

In vivo studies suggest, however, that NK/NKT cells are more involved in rejection than in protecting the graft. Administration of an antibody that depleted almost all NK and NKT cells prior to transplantation of a fully MHC-mismatched DA liver transplant into a Lewis recipient rat prolonged allograft survival from 10 to 19 days, while depletion of host CD8+ T cells did not prevent liver allograft rejection [94]. It is interesting to note that in this model, all intrahepatic NK cells were of host origin as soon as day 3 after transplantation, indicating that at least in this model, rejection was mediated by host NK and/or NKT cells rather than donor NK/NKT cells. However, a recent study showed, by depleting donor NK cells before transplant, that donor liver NK cells were not vitally important for induction of liver transplant tolerance in the PVG to DA rat strain combination [95]. Other studies support a role of NK cells in inducing rejection [96], and in the clinic matching HLA-C (a major inhibitory ligand for NK cells) has also been associated with a better long-term survival of liver transplants [97], thus supporting the hypothesis that NK/NKT cells can induce rejection.

\section{Role of the Hepatic Parenchyma in Liver Transplant Tolerance}

The concept that donor PLs play the most critical role in spontaneous liver transplant acceptance has been relatively popular due to the attractive model of microchimerism and experiments using adoptively transferred donor leukocytes. However, this mechanism alone is not sufficient to explain why liver grafts are accepted spontaneously. As mentioned before, microchimerism is not always associated with graft survival. Furthermore, donor splenocyte administration only prolongs the survival of kidney allografts, but has no effect on the survival of other organs (such as skin and heart) $[42,55]$.

\section{Evidence for a Role of the Liver Tissue in Spontaneous Acceptance of Liver Grafts}

Experiments performed by Calne and colleagues [56] have also emphasized the secondary role of PLs. In these experiments, the donor graft was a chimeric liver in which the migratory PLs were the only cells expressing the alloantigen. This liver was obtained by performing two successive transplants: a PVG strain liver was trans-

Hepatic Parenchyma and Liver

Transplant Tolerance planted into a DA recipient and 20 days later, when the PVG liver was repopulated with DA leukocytes, the liver was retransplanted into a secondary PVG recipient. Although now containing passenger DA leucocytes, the chimeric transplanted liver grafts completely failed to prolong the survival of subsequent DA skin grafts, suggesting that PLs alone were unable to induce tolerance. To examine the role of the nonmigratory cells (liver tissue including hepatocytes, liver sinusoidal endothelial cells, Kupffer cells and stellate cells) in this process, the same investigators generated the reverse transplant chimera, in which a DA liver reconstituted with passenger PVG leukocytes into a PVG rat. In contrast to the other chimeras in which activation was induced by PLs, the survival of DA skin grafts on these chimeric transplant recipients was prolonged in the absence of DA PLs, suggesting that parenchymal cells were able to induce tolerance.

Chiba et al. [55] also confirmed the important role of the liver tissue by reporting a very intriguing finding. They repeated the experiments performed by Sun et al. $[42,46]$ showing that irradiation of a DA liver before transplantation into a PVG host, 24 h later, abrogated the spontaneous acceptance normally observed in this combination. They confirmed that if they reconstituted the donor just after irradiation with DA splenocytes, they could restore spontaneous acceptance of the liver graft. The surprising result was that if they reconstituted the donor with third-party (BN) splenocytes expressing a different allo-MHC molecule, acceptance was also restored. Recipient rats accepting the DA liver graft and injected with DA or BN splenocytes rejected a BN heart, but did not reject a DA heart, indicating that splenocytes restored tolerance regardless of their MHC haplotype and that the specificity of the tolerance depended on the $\mathrm{MHC}$ of the liver tissue rather than on that of splenocytes [55]. By injecting purified $\mathrm{T}$ and $\mathrm{B}$ cells instead of splenocytes, the authors of this study showed that restoration of the tolerance effect was conferred by $\mathrm{T}$ cells and suggested that $\mathrm{T}$ cells secreting immunomodulatory cytokines (potentially $\mathrm{T}_{\text {reg }}$ ) were involved.

These results point out the critical role played by parenchymal cells and the liver tissue in spontaneous acceptance of liver allografts. Similar results were obtained by Kreisel et al. [98] by creating bone marrow chimeric rats: third-party bone marrow was as effective as the bone marrow of donor origin in inducing acceptance of the liver transplant. Again, in these experiments, the liver tissue was important in conferring the MHC specificity [98], arguing against a critical role for PLs in inducing

Dig Dis 2011;29:391-401 
donor-specific tolerance. Similar results were obtained using chimeric mouse models [99].

In summary, there is substantial data in the literature to suggest that the non-bone marrow-derived component of the liver graft (including hepatocytes, liver sinusoidal endothelial cells and potentially stellate cells) play a critical role in inducing donor-specific tolerance. Two nonexclusive models could explain the role of MHC-restriction in this tolerance: soluble MHC molecules and direct $\mathrm{T}$ cell activation by liver cells.

\section{The Role of Liver Tissue in Secreting Soluble MHC Molecules}

The liver secretes soluble MHC class I molecules, and following transplantation, high amounts of these molecules are found in the serum $[17,100]$. This has led some investigators to speculate that soluble MHC molecules might play a role in inducing spontaneous acceptance of liver transplants and be responsible for the effect of the liver tissue (in particular hepatocytes) in this phenomenon. Transplantation of livers from MHC class I-deficient donors did not prevent acceptance of the liver [101], but these studies are hard to interpret as allogeneic $\mathrm{T}$ cells would also ignore MHC class I-deficient liver.

Studies in which recipients were administered soluble MHC molecules are more convincing. Initial studies were disappointing and demonstrated that large quantities of soluble RT1a class I molecule from the DA strain, given intravenously to PVG recipients of DA cardiac allografts by a variety of protocols, did not have any effect on graft survival [102]. Similar results were obtained by other investigators $[103,104]$. Soluble MHC molecules were only effective in prolonging graft survival in combination with cyclosporine treatment [103]. However, these experiments were performed using a single soluble MHC molecule in a complete mismatch combination.

Using a single mismatch MHC molecule combination, Sumimoto and Kamada [105] reported that the daily injection of a DA rat serum (MHC haplotype RT1a) into a PVG (RT1c) rat receiving a heterotopic PVG (RT1a) donor heart allograft prolonged the survival of the graft. Removal of the soluble MHC class I molecules by affinity chromatography abolished the immunosuppressive effect, indicating that MHC molecules were responsible for this result. Moreover, continuous infusion of purified soluble class I antigen from DA rat liver, even from day 4 after heart grafting, induced a significant prolongation of graft survival in a donor-specific manner. A mixture of monoclonal anti-class I (RT1a) antibody with DA serum by continuous infusion amplified the immunosuppres- sive effect [105]. Wang et al. [106] also reported that RT1Aa heavy chain proteins injected into the thymus or into the portal vein 14 days before transplantation induced indefinite survival of ACI liver allografts in Lewis (RT1l) recipients, but only when they were coadministered with anti-T cell receptor $\mathrm{mAb}$ [106]. Further experiments have confirmed the immunosuppressive effect of soluble MHC molecules. Geissler et al. [107] transfected primary cultured Lewis hepatocytes so that they expressed either soluble or membrane-bound MHC class I molecules. By transplanting an ACI (RT1Aa) liver into a Lewis (RT1l) recipient, they demonstrated that hepatocytes secreting RT1Aa molecules injected into the portal vein extended liver allograft survival and decreased CTL activity. Interestingly, in contrast, recipients injected with hepatocytes expressing membrane-bound RT1Aa demonstrated accelerated graft rejection and primed CTLs [107].

The mechanism by which soluble MHC molecules delay graft rejection is still a matter of debate, but it is thought that they play an important role at the very early stages after transplantation by preventing hyperacute graft rejection induced by alloreactive antibodies [108]. Soluble MHC would neutralize these antibodies, hence reducing organ damage and prolonging graft survival. A role for soluble MHC molecules in promoting apoptosis of alloreactive cytotoxic T cells [109] has also been reported. Alternatively, it has been hypothesized that immature host DCs take up peptides derived from donor soluble MHC molecules and present them to recipient $\mathrm{T}$ cells, leading to tolerance $[110,111]$. Consistent with this hypothesis, soluble donor MHC bound to a monoclonal antibody (so that it would be picked up by macrophages and DCs) was more effective in prolonging allograft survival than infusion of soluble donor MHC alone [105]. However, there are also reports demonstrating that this indirect pathway of antigen presentation failed to induce tolerance to subsequent skin transplants [112].

Collectively, these experiments suggest that administration of soluble MHC class I alone has a minimal effect on graft survival by delaying rejection by a few days and, thus, cannot completely account for the role of the parenchyma to induce tolerance. In addition, human studies have shown no correlation between the large quantity of donor HLA in the sera, graft function [113] or a state of tolerance [114]. On the contrary, increased levels of soluble MHC class I has been reported in the setting of rejection or infection [115]. 
The Role of the Liver Tissue in Inducing Abortive

Primary T Cell Activation

Homing and entry of naïve and activated $\mathrm{T}$ cells into lymphoid tissues and organs including the liver are determined by complex molecular interactions involving adhesion molecules that recognize their ligands on endothelial cells [116, 117]. Naïve T lymphocytes do not normally have access to the parenchyma of most organs, as they do not express adhesion molecules and chemokine receptors required for adhesion to endothelial cells or subsequent transendothelial migration [116, 117]. However, naïve T cells express L-selectin (CD62L) which binds to peripheral $\mathrm{LN}$-specific vascular addressins and has been shown to play a critical role in initial binding (tethering) and subsequent rolling of the lymphocytes through the high endothelial venules of the LNs under normal conditions of flow [118]. Chemokines and intercellular adhesion molecule-1/leukocyte function-associated antigen-1 interactions also play an important role in these adhesion steps [118]. In the LNs, naïve T cells interact with professional APCs, in particular DCs, expressing relevant peptide/MHC complexes. This contact induces $\mathrm{T}$ cell activation resulting in expression and upregulation of adhesion molecules, which allows activated $\mathrm{T}$ cells to undergo transendothelial migration and to infiltrate the tissues.

T cells can enter the liver via the sinusoidal endothelium [119]. Sinusoids are formed by monolayers of hepatocytes defining narrow channels approximately $10 \mu \mathrm{m}$ in diameter that are lined by a layer of specialized endothelial cells and liver resident Kupffer cells [120]. Unlike other endothelial cells, liver sinusoidal endothelial cells are perforated by multiple 120 -nm diameter holes (fenestrations), and do not form tight junctions with adjacent endothelial cells [121]. Entry via liver sinusoids is unique as it does not require selectins $[122,123]$. Lack of selectin requirement is thought to be due to a slower or intermittent blood flow that favors intimate contact between leucocytes and liver cells [121]. These unique conditions of slow blood flow, in combination with the narrow diameter of the hepatic sinusoids and their unusual structure favors contact between lymphocytes and liver cells resulting in their retention. Early studies have established that while in the absence of their cognate antigen, naïve $\mathrm{T}$ cells recirculate through the liver without being retained [124-127], and activated CD8+ [124, 126-128] and CD4+ T cells [125] are very efficiently retained in a nonantigen-specific manner, even in the absence of intrahepatically expressed cognate antigen.

Hepatic Parenchyma and Liver

Transplant Tolerance
We have suggested that the ability of the liver to induce tolerance is associated with its unique capability to retain and activate naïve alloreactive or antigen-specific CD8+ $\mathrm{T}$ cells $[123,126,127,129]$. In transplantation, such activation is likely to be mediated by donor liver sinusoidal endothelial cells and Kupffer cells that directly line the sinusoidal lumen [71] and are able to directly contact recipient T cells. Hepatocytes that are located underneath the physical barrier formed by liver sinusoidal endothelial cells could be less accessible, although we have demonstrated that hepatocyte/T cell contacts nevertheless occur via liver sinusoidal endothelial cell fenestrations [120]. Retention and activation of antigen-specific naïve $\mathrm{CD} 8+\mathrm{T}$ cells has been shown in the livers of transgenic mice specifically expressing the cognate antigen in hepatocytes, in the absence of antigen expression in lymphoid tissues. Transgenic $\mathrm{T}$ cells were specifically retained in the livers of recipient mice within minutes and became activated within $2 \mathrm{~h}$ [126], suggesting that the liver is an exception to the general rule of $\mathrm{T}$ cell activation and recirculation, which predicts that naïve $\mathrm{T}$ cells recirculate via the lymph and blood, but do not enter peripheral tissues prior to activation in secondary lymphoid organs. Antigen-presentation by hepatocytes to naïve $\mathrm{CD} 8+\mathrm{T}$ cells was insufficient to promote activation and proliferation of the T cells, which subsequently died by death-byneglect in a Bim-dependent pathway in vitro and in vivo $[130,131]$. We predict that if this retention occurred in transplantation, it would result in the selective depletion of alloreactive T cells, leading to deletional tolerance.

Due to the difficulty of tracking very rare alloreactive $\mathrm{T}$ cells amongst the $\mathrm{T}$ cell repertoire, there has been no study reported to date investigating the retention of alloreactive $\mathrm{T}$ cells within hours after transplantation. However, some of the data in the literature is consistent with a model in which alloreactive $\mathrm{T}$ cells die by neglect. Treatment of rat liver transplant recipients with IL-2, a treatment that overcomes death-by-neglect induced by hepatocyte activation in vitro $[130,131]$ and which is able to rescue anergic $\mathrm{T}$ cells, was able to induce rejection of liver grafts [48].

\section{Conclusion}

Although there is convincing evidence that donor PLs play an important role in the liver tolerance effect, there is also evidence suggesting that the liver tissue itself plays a pivotal role in the antigen-specificity of this phenomenon. It appears that both components, PLs and the paren-

Dig Dis 2011;29:391-401 
chyma, are needed to achieve a state of hyporesponsiveness, as neither the liver parenchyma alone nor donor leukocytes could induce antigen-specific tolerance in robust rodent models. In addition, pre-existing factors like preformed antibodies, prolonged ischemia times or crossreacting memory $\mathrm{T}$ cells might complicate the dissection of liver transplant tolerance in humans and explain why conclusions from small animals are often hard to translate into the clinic.

\section{Acknowledgements}

This work was supported by the Roche Organ Transplantation Research Foundation (ROTRF).

\section{Disclosure Statement}

The authors declare that no financial or other conflict of interest exists in relation to the content of the article.

\section{References}

1 Benseler V, McCaughan GW, Schlitt HJ, Bishop GA, Bowen DG, Bertolino P: The liver: a special case in transplantation tolerance. Semin Liver Dis 2007;27:194-213.

$\checkmark 2$ Kamada N, Wight DG: Antigen-specific immunosuppression induced by liver transplantation in the rat. Transplantation 1984; 38:217-221.

3 Wang C, Sun J, Li L, Wang L, Dolan P, Sheil AG: Conversion of pancreas allograft rejection to acceptance by liver transplantation. Transplantation 1998;65:188-192.

-4 Kamada N, Davies HS, Roser B: Reversal of transplantation immunity by liver grafting. Nature 1981;292:840-842.

$\checkmark 5$ Qian S, Demetris AJ, Murase N, Rao AS, Fung JJ, Starzl TE: Murine liver allograft transplantation: tolerance and donor cell chimerism. Hepatology 1994;19:916-924.

-6 Perry I, Neuberger J: Immunosuppression: towards a logical approach in liver transplantation. Clin Exp Immunol 2005;139:210.

7 Wiesner RH, Demetris AJ, Belle SH, Seaberg EC, Lake JR, Zetterman RK, Everhart J, Detre KM: Acute hepatic allograft rejection: incidence, risk factors, and impact on outcome. Hepatology 1998;28:638-645.

$\checkmark 8$ Ramos HC, Reyes J, Abu-Elmagd K, Zeevi A, Reinsmoen N, Tzakis A, Demetris AJ, Fung JJ, Flynn B, McMichael J: Weaning of immunosuppression in long-term liver transplant recipients. Transplantation 1995;59:212-217.

-9 Takatsuki M, Uemoto S, Inomata Y, Egawa H, Kiuchi T, Fujita S, Hayashi M, Kanematsu $\mathrm{T}$, Tanaka K: Weaning of immunosuppression in living donor liver transplant recipients. Transplantation 2001;72:449-454.

$\checkmark 10$ Lerut J, Sanchez-Fueyo A: An appraisal of tolerance in liver transplantation. Am J Transplant 2006;6:1774-1780.

-11 Castellaneta A, Thomson AW, Nayyar N, de Vera M, Mazariegos GV: Monitoring the operationally tolerant liver allograft recipient. Curr Opin Organ Transplant 2010;15:28-34.
12 Rokahr KL, Sharland AF, Sun J, Wang C, Sheil AG, Yan Y, McCaughan GW, Bishop GA: Paradoxical early immune activation during acceptance of liver allografts compared with rejection of skin grafts in a rat model of transplantation. Immunology 1998;95:257-263.

13 Bishop GA, Wang C, Sharland AF, McCaughan G: Spontaneous acceptance of liver transplants in rodents: evidence that liver leucocytes induce recipient T-cell death by neglect. Immunol Cell Biol 2002;80:93-100.

14 Calne RY: Strange English pigs. Lancet 1969; 2:940-941.

15 Calne RY, Sells RA, Pena JR, Davis DR, Millard PR, Herbertson BM, Binns RM, Davies DAL: Induction of immunological tolerance by porcine liver allografts. Nature 1969;223: 472-476.

16 Houssin D, Gigou M, Franco D, Bismuth H, Charpentier B, Lang P, Martin E: Specific transplantation tolerance induced by spontaneously tolerated liver allograft in inbred strains of rats. Transplantation 1980;29:418419.

17 Kamada N, Brons G, Davies HS: Fully allogeneic liver grafting in rats induces a state of systemic nonreactivity to donor transplantation antigens. Transplantation 1980;29:429431.

18 Zimmermann FA, Davies HS, Knoll PP, Gokel JM, Schmidt T: Orthotopic liver allografts in the rat. The influence of strain combination on the fate of the graft. Transplantation 1984;37:406-410.

19 Sugioka A, Morita M, Fujita J, Hasumi A, Shiroishi T: Graft acceptance and tolerance induction in mouse liver transplantation using wild mice. Transplant Proc 2001;33:137139.

20 Gallico GG, Butcher GW, Howard JC: The role of subregions of the rat major histocompatibility complex in the rejection and passive enhancement of renal allografts. J Exp Med 1979;149:244-253.

21 Hall BM, Dorsch S, Roser B: The cellular basis of allograft rejection in vivo. I. The cellular requirements for first-set rejection of heart grafts. J Exp Med 1978;148:878-889.
22 Doyle HR, Marino IR, Morelli F, Doria C, Aldrighetti L, McMichael J, Martell J, Gayowski T, Starzl TE: Assessing risk in liver transplantation. Special reference to the significance of a positive cytotoxic crossmatch. Ann Surg 1996;224:168-177.

23 Opelz G, Wujciak T, Dohler B, Scherer S, Mytilineos J: HLA compatibility and organ transplant survival. Collaborative transplant study. Rev Immunogenet 1999;1:334342.

24 Sugawara Y, Tamura S, Kaneko J, Togashi J, Makuuchi M, Kokudo N: Positive lymphocytotoxic crossmatch does not adversely affect survival in living donor liver transplantation. Dig Surg 2009;26:482-486.

25 Olausson M, Mjornstedt L, Norden G, Rydberg L, Molne J, Backman L, Friman S: Successful combined partial auxiliary liver and kidney transplantation in highly sensitized cross-match positive recipients. Am J Transplant 2007;7:130-136.

26 Kamada N: The immunology of experimental liver transplantation in the rat. Immunology 1985;55:369-389.

27 Rasmussen A, Davies HF, Jamieson NV, Evans DB, Calne RY: Combined transplantation of liver and kidney from the same donor protects the kidney from rejection and improves kidney graft survival. Transplantation 1995;59:919-921.

28 Raichlin E, Daly RC, Rosen CB, McGregor CG, Charlton MR, Frantz RP, Clavell AL, Rodeheffer RJ, Pereira NL, Kremers WK, Kushwaha SS, Edwards BS: Combined heart and liver transplantation: a single-center experience. Transplantation 2009;88:219-225.

29 Praseedom RK, McNeil KD, Watson CJ, Alexander GJ, Calne RY, Wallwork J, Friend PJ: Combined transplantation of the heart, lung, and liver. Lancet 2001;358:812-813.

30 Limmer J, Herbertson BM, Calne RY: Orthotopic rat liver transplantation using different combinations of four inbred strains. Eur Surg Res 1980;12:343-348. 
-31 Sun J, McCaughan GW, Matsumoto Y, Sheil AG, Gallagher ND, Bishop GA: Tolerance to rat liver allografts. I. Differences between tolerance and rejection are more marked in the $\mathrm{B}$ cell compared with the $\mathrm{T}$ cell or $\mathrm{cy}$ tokine response. Transplantation 1994;57: 1349-1357.

- 32 Knechtle SJ, Kolbeck PC, Tsuchimoto S, Coundouriotis A, Sanfilippo F, Bollinger RR: Hepatic transplantation into sensitized recipients. Demonstration of hyperacute rejection. Transplantation 1987;43:8-12.

- 33 Krams SM, Egawa H, Quinn MB, Villanueva JC, Garcia-Kennedy R, Martinez OM: Apoptosis as a mechanism of cell death in liver allograft rejection. Transplantation 1995;59: 621-625.

- 34 Afford SC, Hubscher S, Strain AJ, Adams $\mathrm{DH}$, Neuberger JM: Apoptosis in the human liver during allograft rejection and end-stage liver disease. J Pathol 1995;176:373-380.

- 35 Hayashi A, Ito H, Shomori K, Ohdan H, Yano K, Asahara T: Frequent occurrence of hepatocytic apoptosis in acute rejection of the grafted rat liver. Pathol Int 1997;47:518-524.

- 36 Sharland A, Yan Y, Wang C, Bowen DG, Sun J, Sheil AG, McCaughan GW, Bishop GA: Evidence that apoptosis of activated T cells occurs in spontaneous tolerance of liver allografts and is blocked by manipulations which break tolerance. Transplantation 1999;68:1736-1745.

-37 Lu L, Li W, Zhong C, Qian S, Fung JJ, Thomson AW, Starzl TE: Increased apoptosis of immunoreactive host cells and augmented donor leukocyte chimerism, not sustained inhibition of B7 molecule expression are associated with prolonged cardiac allograft survival in mice preconditioned with immature donor dendritic cells plus anti-CD40Ll mAb. Transplantation 1999;68:747-757.

- 38 Chen Y, Yan T, Shi LJ, Liu Z, Liang SY, Luan XF, Long FW, Chen J, Peng Y, Yan LN, Gong JP: Knockdown of interleukin-2 by shRNAmediated RNA interference prolongs liver allograft survival. J Surg Res 2011;159:582587.

-39 Qian S, Lu L, Fu F, Li Y, Li W, Starzl TE, Fung JJ, Thomson AW: Apoptosis within spontaneously accepted mouse liver allografts: evidence for deletion of cytotoxic T cells and implications for tolerance induction. J Immunol 1997;158:4654-4661.

-40 Sharland A, Shastry S, Wang C, Rokahr K, Sun J, Sheil AG, McCaughan GW, Bishop GA: Kinetics of intragraft cytokine expression, cellular infiltration, and cell death in rejection of renal allografts compared with acceptance of liver allografts in a rat model: early activation and apoptosis is associated with liver graft acceptance. Transplantation 1998;65:1370-1377.
41 Bishop GA, Sun J, DeCruz DJ, Rokahr KL, Sedgwick JD, Sheil AG, Gallagher ND, McCaughan GW: Tolerance to rat liver allografts. III. Donor cell migration and tolerance-associated cytokine production in peripheral lymphoid tissues. J Immunol 1996; 156:4925-4931.

42 Sun J, Sheil AG, Wang C, Wang L, Rokahr K, Sharland A, Jung SE, Li L, McCaughan GW, Bishop GA: Tolerance to rat liver allografts: IV. Acceptance depends on the quantity of donor tissue and on donor leukocytes. Transplantation 1996;62:1725-1730.

43 Sarris GE, Smith JA, Shumway NE, Stinson EB, Oyer PE, Robbins RC, Billingham ME, Theodore J, Moore KA, Reitz BA: Long-term results of combined heart-lung transplantation: the Stanford experience. J Heart Lung Transplant 1994;13:940-949.

44 Narula J, Bennett LE, DiSalvo T, Hosenpud JD, Semigran MJ, Dec GW: Outcomes in recipients of combined heart-kidney transplantation: multiorgan, same-donor transplant study of the international society of heart and lung transplantation/united network for organ sharing scientific registry. Transplantation 1997;63:861-867.

45 Rana A, Robles S, Russo MJ, Halazun KJ, Woodland DC, Witkowski P, Ratner LE, Hardy MA: The combined organ effect: protection against rejection? Ann Surg 2008; 248:871-879.

46 Sun J, McCaughan GW, Gallagher ND, Sheil AG, Bishop GA: Deletion of spontaneous rat liver allograft acceptance by donor irradiation. Transplantation 1995;60:233-236.

-47 Shimizu Y, Goto S, Lord R, Vari F, EdwardsSmith C, Chiba S, Schlect D, Buckley M, Kusano M, Kamada N: Restoration of tolerance to rat hepatic allografts by spleen-derived passenger leukocytes. Transpl Int 1996;9: 593-595.

48 Tu YZ, Arima T, Flye MW: Rejection of spontaneously accepted rat liver allografts with recipient interleukin-2 treatment or donor irradiation. Transplantation 1997;63:177-181.

-49 Starzl TE, Demetris AJ, Murase N, Ildstad S, Ricordi C, Trucco M: Cell migration, chimerism, and graft acceptance. Lancet 1992;339: 1579-1582.

50 Starzl TE, Demetris AJ, Trucco M, et al: Cell migration and chimerism after whole-organ transplantation: the basis of graft acceptance. Hepatology 1993;17:1127-1152.

51 Starzl TE, Lakkis FG: The unfinished legacy of liver transplantation: emphasis on immunology. Hepatology 2006;43:S151-S163.

52 Devlin J, Doherty D, Thomson L, Wong T, Donaldson P, Portmann B, Williams R: Defining the outcome of immunosuppression withdrawal after liver transplantation. Hepatology 1998;27:926-933.

- 53 Girlanda R, Rela M, Williams R, O’Grady JG, Heaton ND: Long-term outcome of immunosuppression withdrawal after liver transplantation. Transplant Proc 2005;37: 1708-1709.
54 Wood K, Sachs DH: Chimerism and transplantation tolerance: cause and effect. Immunol Today 1996;17:584-587, discussion 588 .

55 Chiba S, Goto S, Shimizu Y, Vari F, Lord R, Edwards-Smith C, Kobayashi S, Ochiai T, Isono $\mathrm{K}$ : The characterization of reconstituted passenger leukocytes on the induction of tolerance in rat liver transplantation. Transpl Int 1997;10:350-356.

56 Sriwatanawongsa V, Davies HS, Calne RY: The essential roles of parenchymal tissues and passenger leukocytes in the tolerance induced by liver grafting in rats. Nat Med 1995; 1:428-432.

57 Limmer A, Sacher T, Alferink J, Nichterlein T, Arnold B, Hammerling GJ: A two-step model for the induction of organ-specific autoimmunity. Novartis Found Symp 1998; 215:159-167, discussion 167-171.

58 Gannage M, Buzyn A, Bogiatzi SI, Lambert M, Soumelis V, Dal Cortivo L, CavazzanaCalvo M, Brousse N, Caillat-Zucman S: Induction of NKG2D ligands by gamma radiation and tumor necrosis factor-alpha may participate in the tissue damage during acute graft-versus-host disease. Transplantation 2008;85:911-915.

59 den Dulk M, Wang C, Li J, Clark DA, Hibberd AD, Terpstra OT, McCaughan GW, Bishop GA: Combined donor leucocyte administration and immunosuppressive drug treatment for survival of rat heart allografts. Transpl Immunol 2004;13:177-184.

-60 Tsui TY, Jager MD, Deiwick A, Aselmann H, Neipp M, Fan ST, Schlitt HJ: Delayed lowlevel calcineurin inhibition promotes allospecific tolerance induction by posttransplantation donor leukocyte infusion. Transplantation 2002;73:1325-1332.

61 Siemionow M, Agaoglu G: Role of blood transfusion in transplantation: a review. J Reconstr Microsurg 2005;21:555-563.

62 Yan Y, Shastry S, Richards C, Wang C, Bowen DG, Sharland AF, Painter DM, McCaughan GW, Bishop GA: Posttransplant administration of donor leukocytes induces long-term acceptance of kidney or liver transplants by an activation-associated immune mechanism. J Immunol 2001; 166: 5258-5264.

63 Tsui TY, Deiwick A, Ko S, Schlitt HJ: Specific immunosuppression by postoperative infusion of allogeneic spleen cells: requirement of donor major histocompatibility complex expression and graft-versus-host reactivity. Transplantation 2000;69:25-30.

64 Sebille F, Brouard S, Petzold T, Degauque N, Guillet M, Moreau A, Benjamin CD, Soulillou JP: Tolerance induction in rats, using a combination of anti-CD154 and donor splenocytes, given once on the day of transplantation. Transplantation 2003;75:169-172.

65 Fuchs EJ, Matzinger P: B cells turn off virgin but not memory T cells. Science 1992;258: 1156-1159. 
-66 Yan Y, van der Putten K, Bowen DG, Painter DM, Kohar J, Sharland AF, McCaughan GW, Bishop GA: Postoperative administration of donor B cells induces rat kidney allograft acceptance: lack of association with Th2 cytokine expression in long-term accepted grafts. Transplantation 2002;73: 1123-1130.

67 Thomson A, Lu L: Are dendritic cells the key to liver transplant tolerance? Immunol Today 1999;20:27-32.

-68 Woo J, Lu L, Rao AS, Li Y, Subbotin V, Starzl TE, Thomson AW: Isolation, phenotype, and allostimulatory activity of mouse liver dendritic cells. Transplantation 1994;58:484491.

69 Mackay IR: Hepatoimmunology: a perspective. Immunol Cell Biol 2002;80:36-44.

-70 Steptoe RJ, Li W, Fu F, O'Connell PJ, Thomson AW: Trafficking of APC from liver allografts of Flt3L-treated donors: augmentation of potent allostimulatory cells in recipient lymphoid tissue is associated with a switch from tolerance to rejection. Transpl Immunol 1999;7:51-57.

-71 Bertolino P, McCaughan GW, Bowen DG: Role of primary intrahepatic T-cell activation in the 'liver tolerance effect'. Immunol Cell Biol 2002;80:84-92.

72 Chiang YJ, Lu L, Fung JJ, Qian S: Liver-derived dendritic cells induce donor-specific hyporesponsiveness: use of sponge implant as a cell transplant model. Cell Transplant 2001; 10:343-350.

73 Bertolino P, McCaughan GW, Bowen DG: Role of primary intrahepatic T-cell activation in the 'liver tolerance effect'. Immunol Cell Biol 2002;80:84-92.

74 Thomson AW, Drakes ML, Zahorchak AF, O’Connell PJ, Steptoe RJ, Qian S, Lu L: Hepatic dendritic cells: immunobiology and role in liver transplantation. J Leukoc Biol 1999;66:322-330.

-75 Goddard S, Hubscher S, Lane P, Adams D: A comparison of dendritic cells migrated from human liver and skin. Scand J Immunol 2001;54:abstract 341.

-76 De Creus A, Abe M, Lau AH, Hackstein H, Raimondi G, Thomson AW: Low TLR4 expression by liver dendritic cells correlates with reduced capacity to activate allogeneic $\mathrm{T}$ cells in response to endotoxin. J Immunol 2005; 174:2037-2045.

-77 Thomson AW, Lu L, Murase N, Demetris AJ, Rao AS, Starzl TE: Microchimerism, dendritic cell progenitors and transplantation tolerance. Stem Cells 1995;13:622-639.

-78 Kabelitz D, Wesch D, Oberg HH: Regulation of regulatory T cells: role of dendritic cells and Toll-like receptors. Crit Rev Immunol 2006;26:291-306.

79 Yamazaki S, Inaba K, Tarbell KV, Steinman RM: Dendritic cells expand antigen-specific Foxp3+ CD25+ CD4+ regulatory T cells including suppressors of alloreactivity. Immunol Rev 2006;212:314-329.
80 Qian S, Lu L, Fu F, Li W, Pan F, Steptoe RJ, Chambers FG, Starzl TE, Fung JJ, Thomson AW: Donor pretreatment with Flt-3 ligand augments anti-donor cytotoxic $\mathrm{T}$ lymphocyte, natural killer, and lymphocyte-activated killer cell activities within liver allografts and alters the pattern of intragraft apoptotic activity. Transplantation 1998;65:15901598.

81 Bamboat ZM, Stableford JA, Plitas G, Burt BM, Nguyen HM, Welles AP, Gonen M, Young JW, DeMatteo RP: Human liver dendritic cells promote $\mathrm{T}$ cell hyporesponsiveness. J Immunol 2009;182:1901-1911.

82 Bonham CA, Lu L, Banas RA, Fontes P, Rao AS, Starzl TE, Zeevi A, Thomson AW: TGFbeta 1 pretreatment impairs the allostimulatory function of human bone marrow-derived antigen-presenting cells for both naive and primed T cells. Transpl Immunol 1996; 4:186-191.

83 Menges M, Rossner S, Voigtlander C, Schindler H, Kukutsch NA, Bogdan C, Erb $\mathrm{K}$, Schuler G, Lutz MB: Repetitive injections of dendritic cells matured with tumor necrosis factor alpha induce antigen-specific protection of mice from autoimmunity. J Exp Med 2002;195:15-21.

84 Huang YL, Wang YZ, Chen JB, Wang F, Kang XP, Xia JJ, Lan TS, Xie BY, Ekberg H, Wang XM, Qi ZQ: Prevention of acute and chronic allograft rejection by combinations of tolerogenic dendritic cells. Scand J Immunol 2011;73:91-101.

85 Taniguchi H, Toyoshima T, Fukao K, Nakauchi H: Presence of hematopoietic stem cells in the adult liver. Nat Med 1996;2:198203.

86 Halder RC, Seki S, Weerasinghe A, Kawamura $\mathrm{T}$, Watanabe $\mathrm{H}, \mathrm{Abo} \mathrm{T}$ : Characterization of NK cells and extrathymic T cells generated in the liver of irradiated mice with a liver shield. Clin Exp Immunol 1998;114:434447.

87 Good RA: Mixed chimerism and immunologic tolerance. N Engl J Med 1993;328:801802.

Sykes M: Chimerism and central tolerance. Curr Opin Immunol 1996;8:694-703.

89 Kobayashi E, Kamada N, Delriviere L, Lord R, Goto S, Walker NI, Enosawa S, Miyata M: Migration of donor cells into the thymus is not essential for induction and maintenance of systemic tolerance after liver transplantation in the rat. Immunology 1995;84:333336.

90 Pruvot FR, Navarro F, Janin A, Labalette M, Masy E, Lecomte-Houcke M, Gambiez L, Copin MC, Dessaint JP: Characterization, quantification, and localization of passenger T lymphocytes and NK cells in human liver before transplantation. Transpl Int 1995;8: 273-279.
91 Navarro F, Portales P, Candon S, Pruvot FR, Pageaux G, Fabre JM, Domergue J, Clot J: Natural killer cell and alphabeta and gammadelta lymphocyte traffic into the liver graft immediately after liver transplantation. Transplantation 2000;69:633-639.

-92 Jinushi M, Takehara T, Tatsumi T, Yamaguchi S, Sakamori R, Hiramatsu N, Kanto T, Ohkawa K, Hayashi N: Natural killer cell and hepatic cell interaction via NKG2A leads to dendritic cell-mediated induction of CD4 CD25 T cells with PD-1-dependent regulatory activities. Immunology 2007; 120:73-82.

93 Wahl C, Bochtler P, Schirmbeck R, Reimann J: Type I IFN-producing CD4 Valpha14i NKT cells facilitate priming of IL10 -producing CD8 T cells by hepatocytes. J Immunol 2007;178:2083-2093.

94 Ogura Y, Martinez OM, Villanueva JC, Tait JF, Strauss HW, Higgins JP, Tanaka K, Esquivel CO, Blankenberg FG, Krams SM Apoptosis and allograft rejection in the absence of CD8+ T cells. Transplantation 2001;71:1827-1834.

95 van Leest Y, Moroso V, Wang C, Tay SS, Cunningham E, Ilie V, Bishop A, Kwekkeboom J: No evidence for involvement of donor NK cells in liver transplant tolerance. Transpl Immunol 2011;24:138-139.

-96 Shen K, Zheng SS, Park O, Wang H, Sun Z, Gao B: Activation of innate immunity (NK/ IFN-gamma) in rat allogeneic liver transplantation: contribution to liver injury and suppression of hepatocyte proliferation. Am J Physiol Gastrointest Liver Physiol 2008;294:G1070-G1077.

-97 Hanvesakul R, Spencer N, Cook M, Gunson B, Hathaway M, Brown R, Nightingale P, Cockwell P, Hubscher SG, Adams DH, Moss P, Briggs D: Donor HLA-C genotype has a profound impact on the clinical outcome following liver transplantation. Am J Transplant 2008;8:1931-1941.

98 Kreisel D, Petrowsky H, Krasinskas AM, Krupnick AS, Szeto WY, McLean AD, Popma SH, Gelman AE, Traum MK, Furth EE, Moore JS, Rosengard BR: The role of passenger leukocyte genotype in rejection and acceptance of rat liver allografts. Transplantation 2002;73:1501-1507.

-99 Thai NL, Qian S, Fu F, Li Y, Sun H, Demetris AJ, Duquesnoy RJ, Starzl TE, Fung JJ: Mouse liver transplantation tolerance: the role of hepatocytes and nonparenchymal cells. Transplant Proc 1995;27:509-510.

100 Davies HS, Pollard SG, Calne RY: Soluble HLA antigens in the circulation of liver graft recipients. Transplantation 1989;47: 524-527.

101 Qian S, Fu F, Li Y, Lu L, Rao AS, Starzl TE, Thomson AW, Fung JJ: Impact of donor MHC class I or class II antigen deficiency on first- and second-set rejection of mouse heart or liver allografts. Immunology 1996; $88: 124-129$ 
102 Spencer SC, Fabre JW: Bulk purification of a naturally occurring soluble form of RT1-A class I major histocompatibility complex antigens from DA rat liver, and studies of specific immunosuppression. Transplantation 1987;44:141-148.

103 Foster S, Wood KJ, Morris PJ: The effectiveness of pretreatment with soluble or membrane-bound donor class I major histocompatibility complex antigens in the induction of unresponsiveness to a subsequent rat renal allograft. Transplantation 1992; 53:1322-1328.

104 Priestley CA, Dalchau R, Sawyer GJ, Fabre JW: A detailed analysis of the potential of water-soluble classical class I MHC molecules for the suppression of kidney allograft rejection and in vitro cytotoxic $\mathrm{T}$ cell responses. Transplantation 1989;48:10311038.

105 Sumimoto R, Kamada N: Specific suppression of allograft rejection by soluble class I antigen and complexes with monoclonal antibody. Transplantation 1990;50:678682.

106 Wang M, Stepkowski SM, Wang ME, Tian L, Qu X, Tu Y, He G, Kahan BD: Induction of specific allograft immunity by soluble class I MHC heavy chain protein produced in a baculovirus expression system. Transplantation 1996;61:448-457.

107 Geissler EK, Korzun WJ, Graeb C: Secreted donor-MHC class I antigen prolongs liver allograft survival and inhibits recipient anti-donor cytotoxic T lymphocyte responses. Transplantation 1997;64:782-786.

108 Kamada N, Goto S, Lord R, Sunagawa M: Powerful immunosuppression by a new 40 $\mathrm{kd}$ serum protein (KX-5) induced by liver transplantation. Transplant Proc 1996;28: 3112.

109 Zavazava N, Kronke M: Soluble HLA class I molecules induce apoptosis in alloreactive cytotoxic T lymphocytes. Nat Med 1996;2: 1005-1010.

110 Hawiger D, Inaba K, Dorsett Y, Guo M, Mahnke K, Rivera M, Ravetch JV, Steinman RM, Nussenzweig MC: Dendritic cells induce peripheral $\mathrm{T}$ cell unresponsiveness under steady state conditions in vivo. J Exp Med 2001;194:769-779.
1 Steinman RM, Hawiger D, Nussenzweig MC: Tolerogenic dendritic cells. Annu Rev Immunol 2003;21:685-711.

112 Del Rio ML, Cote-Sierra J, Rodriguez-Barbosa JI: Flt3L-mobilized dendritic cells bearing $\mathrm{H} 2-\mathrm{Kbm} 1$ apoptotic cells do not induce cross-tolerance to CD8(+) T cells across a class I MHC mismatched barrier. Transpl Int 2011;24:501-513.

113 Chauhan B, Mathew JM, Shenoy S, Flye MW, Howard T, Mohanakumar T: Donor human leukocyte antigens in the circulation of liver allograft recipients. Clin Transplant 1995;9:14-19.

114 McMillan RW, Gelder FB, Zibari GB, Aultman DF, Adamashvili I, McDonald JC: Soluble fraction of class I human histocompatibility leukocyte antigens in the serum of liver transplant recipients. Clin Transplant 1997;11:98-103.

115 Rhynes VK, McDonald JC, Gelder FB, Aultman DF, Hayes JM, McMillan RW, Mancini MC: Soluble HLA class I in the serum of transplant recipients. Ann Surg 1993;217:485-489, discussion 489-491.

116 Mackay CR, Marston WL, Dudler L: Naive and memory $\mathrm{T}$ cells show distinct pathways of lymphocyte recirculation. J Exp Med 1990;171:801-817.

117 Selmi C, Mackay IR, Gershwin ME: The immunological milieu of the liver. Semin Liver Dis 2007;27:129-139.

118 Salmi M, Adams D, Jalkanen S: Cell adhesion and migration. IV. Lymphocyte trafficking in the intestine and liver. Am J Physiol 1998;274:G1-G6.

119 Holz LE, McCaughan GW, Benseler V, Bertolino P, Bowen DG: Liver tolerance and the manipulation of immune outcomes. Inflamm Allergy Drug Targets 2008;7:6-18.

120 Warren A, Le Couteur D, Fraser R, Bowen DG, McCaughan GW, Bertolino P: T lymphocytes interact with hepatocytes through fenestrations in liver sinusoidal endothelial cells. Hepatology 2006;44:1182-1190.

121 MacSween RNM, Scothorne RJ: Developmental anatomy and normal structure; in MacSween RNM, Anthony PP, Scheuer PJ (eds): Pathology of the Liver. New York, Churchill Livingstone, 1979, pp 1-49.
122 Wong J, Johnston B, Lee SS, Bullard DC, Smith CW, Beaudet AL, Kubes P: A minimal role for selectins in the recruitment of leukocytes into the inflamed liver microvasculature. J Clin Invest 1997;99:27822790.

123 Bowen DG, Zen M, Holz L, Davis T, McCaughan GW, Bertolino P: The site of primary $\mathrm{T}$ cell activation is a determinant of the balance between intrahepatic tolerance and immunity. J Clin Invest 2004;114 701-712.

124 Mehal WZ, Juedes AE, Crispe IN: Selective retention of activated CD8+ T cells by the normal liver. J Immunol 1999;163:32023210.

125 Hamann A, Klugewitz K, Austrup F, Jablonski-Westrich D: Activation induces rapid and profound alterations in the trafficking of T cells. Eur J Immunol 2000;30: 3207-3218.

126 Bertolino P, Bowen DG, McCaughan GW, Fazekas De St Groth B: Antigen-specific primary activation of $\mathrm{CD} 8+\mathrm{T}$ cells within the liver. J Immunol 2001;166:5430-5438.

127 Bowen DG, Warren A, Davis T, Hoffmann MW, McCaughan GW, Fazekas de St Groth BF, Bertolino P: Cytokine-dependent bystander hepatitis due to intrahepatic murine CD8+ T-cell activation by bone marrow-derived cells. Gastroenterology 2002; 123:1252-1264.

128 Ando K, Guidotti LG, Cerny A, Ishikawa T, Chisari FV: CTL access to tissue antigen is restricted in vivo. J Immunol 1994;153: 482-488.

129 Bowen DG, McCaughan G, Bertolino P: Intrahepatic immunity: a tale of two sites? Trends Immunol 2005;26:512-517.

130 Bertolino P, Trescol-Biemont MC, Thomas J, Fazekas de St Groth B, Pihlgren M, Marvel J, Rabourdin-Combe C: Death by neglect as a deletional mechanism of peripheral tolerance. Int Immunol 1999; 11:12251238.

131 Holz LE, Benseler V, Bowen DG, Bouillet P, Strasser A, O'Reilly L, d'Avigdor WM, Bishop AG, McCaughan GW, Bertolino P: Intrahepatic murine CD8 T-cell activation associates with a distinct phenotype leading to Bim-dependent death. Gastroenterology 2008;135:989-997. 